\title{
Patterns of plant diversity and endemism in Namibia
}

\author{
P. CRAVEN* and P. VORSTER**
}

Keywords: Namibia, phytogeography, plant endemism

\author{
ABSTRACT
}

Species richness, endemism and areas that are rich in both species and endemic species were assessed and mapped for Namibia. High species diversity corresponds with zones where species overlap. These are particularly obvious where there are altitudinal variations and in high-lying areas. The endemic flora of Namibia is rich and diverse. An estimated $16 \%$ of the total plant species in Namibia are endemic to the country. Endemics are in a wide variety of families and sixteen genera are endemic. Factors that increase the likelihood of endemism are mountains, hot deserts, diversity of substrates and microclimates. The distribution of plants endemic to Namibia was arranged in three different ways. Firstly, based on a grid count with the phytogeographic value of the species being equal, overall endemism was mapped. Secondly, range restricted plant species were mapped individually and those with congruent distribution patterns were combined. Thirdly. localities that are important for very range-restricted species were identified. The resulting maps of endemism and diversity were compared and found to correspond in many localities. When overall endemism is compared with overall diversity. rich localities may consist of endemic species with wide ranges. The other methods identify important localities with their own distinctive complement of species.

\section{INTRODUCTION}

Species diversity was traditionally measured by counting the number of different species recorded in a specific area or grid (Linder 2001). The 'weight' of the species was not taken into consideration. Today various measures of diversity have been proposed that give greater value to species that are taxonomically, geographically, ecologically or economically distinct, but no 'best' method for mapping species diversity has yet been found (Craven $2002 \mathrm{~b}$ ). The development of floristic databanks allows quick and efficient retrieval of phytogeographic data that can produce computerized distribution maps. This study used the computerized data of specimens housed in the National Herbarium of Namibia (WIND) and the National Herbarium in Pretoria (PRE) to survey distribution patterns of plant diversity, overall endemism and centres of endemism and diversity on a quarter-degree scale in Namibia. The endemic flora were also analysed and factors that may have contributed to the resulting distribution patterns were discussed briefly when evident from the use of map overlays. Known centres of endemism were not redefined, only species with similar patterns of distribution were recorded.

Caldecott et al. (1996) separated the current knowledge of biodiversity into global, regional, national, ecoregional and site information. Patterns of diversity in Namibia have been shown on continental-scale diversity maps (Mutke et al. 2001) and included in region-based studies such as those of Goldblatt (1978), Cowling et al. (1989) and (jibbs Russell (1985, 1987). The account of Linder $(2001)$ on patterns of plant species endemism and richness for the African flora does not include arid areas such as most of Namibia.

The first national assessment and map of relative species richness in Namibia was that of Maggs et al.

\footnotetext{
* To whom correspondence should be addressed: P.O. Box 399. Omaruru, Namibia.

* Botany Department. University of Stellenbosch. Private Bag X1. 7602 Matieland. Stellenbosch

MS. received: $20(04-(07-29$.
}

(1994). It was based on distributional data per magisterial district following Merxmüller (1966-1972), as well as other literature. Species diversity was re-assessed for the Biodiversity Country and mapped on half-degree grid squares (Maggs 1998; Maggs et al. 1998). This study updates the underlying data used in Maggs (1998) on a finer scale.

A taxon is endemic if confined to a particular area (Major 1988) which may be large or small. Clearly, data on endemism would be more useful if given by floristic province rather than political divisions (Major 1988; Van Wyk \& Smith 2001), but datasets between different countries are seldom compatible in quality or quantity. Due to the fact that Namibia is home to a considerable number of endemics with adequate data, this assessment only reviews species limited to Namibia (Figure 1). An endemic is therefore defined here as a taxon that is restricted to within the political borders of Namibia. Taxa that extend marginally into another region, i.e. beyond the political borders of Namibia are referred to as nearendemic.

Centres of outstanding species diversity and endemism such as the Kaokoveld and Gariep have long attracted attention, but their boundaries, floristic elements and origins remain fairly sketchy. Different approaches and methodologies have also contributed to the centres (sometimes with the same name) not being compatible or comparable (Van Wyk \& Smith 2001; Craven 2002b). Stott (1981) suggested that the process consists of stages i.e. after taxonomic study (essential for elucidating closely related taxonomic units) using specimens, species distributions are plotted and areas of congruence identified. The plants are then arranged into recognizable groups, which on further analysis would identify phytogeographic centres determined by a high concentration of taxa with restricted distributions. This approach was pioneered in southern Africa by Weimarck (1941) and is found in taxonomic literature, for example in Nordenstam (1969) and Hilliard (1994). The approach looks at the geographical ranges of species regardless of their growth form or other factors such as topography and present 


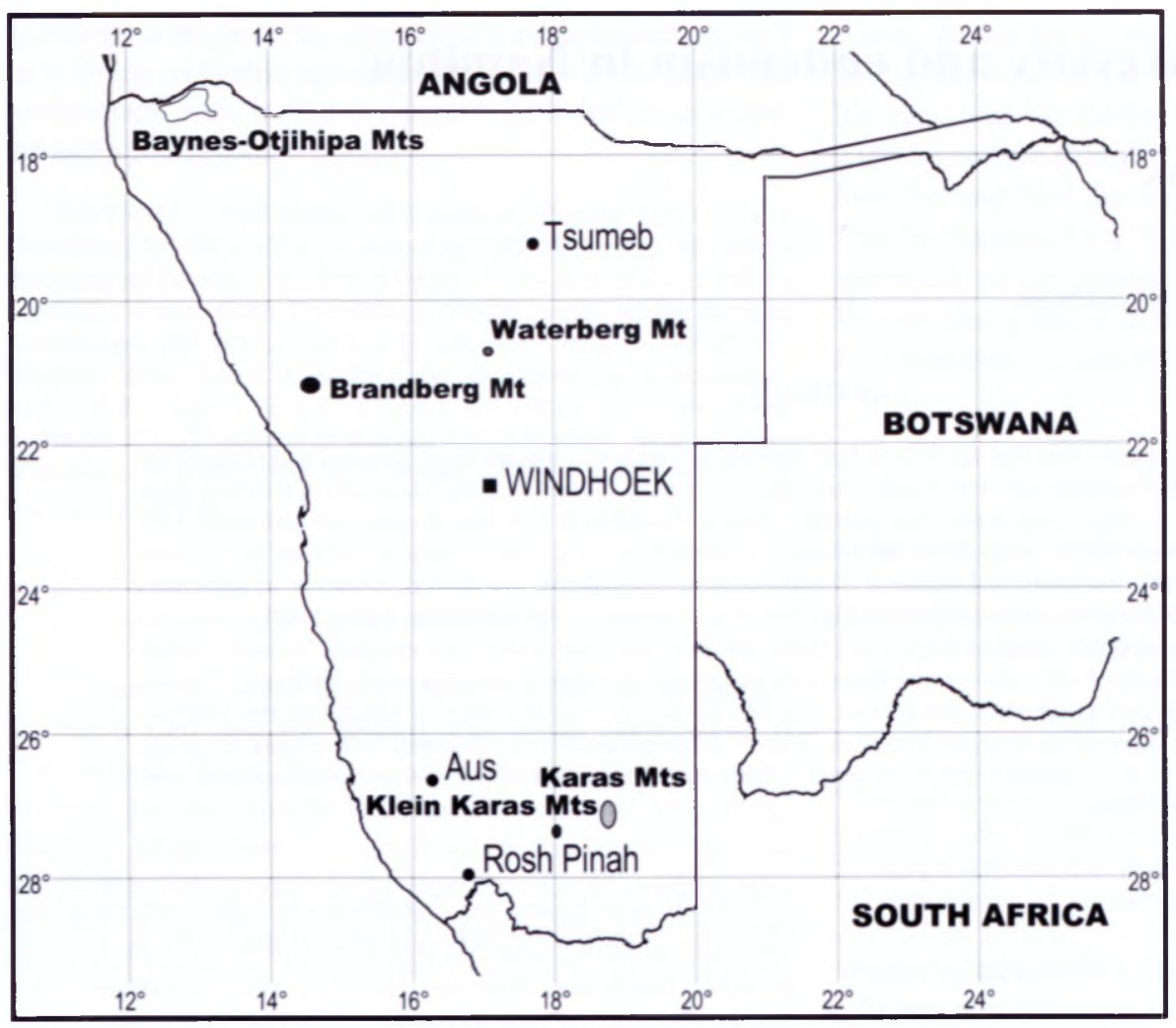

FIGURE 1.-Namibia, its neighbours, capital city and some important mountains and towns.

climate, and identifies particular geographical areas inhabited by species that are restricted to these ranges. Once such a centre is recognized, explanations are sought on how they may have arisen (e.g. past climate) and how they are being maintained. This knowledge is fundamental to understanding the origin, migration, and speciation of plants and is essential for developing strategies for biological conservation. This study did not attempt to redefine the centres presently known for Namibia, but attributes a number of new species to the centres.

Maps presenting overall patterns of diversity and endemism in Namibia have been used to identify regions of importance for conservation (Simmons et al. 1998; Mendelsohn et al. 2002). This paper shows two other methods of mapping important areas for endemics, which should also be taken into consideration.

\section{MATERIALS AND METHODS}

\section{Database}

Georeferenced specimens on the specimen database (SPMNDB) in WIND provided the grid-diversity count. This database has \pm 120000 specimens and includes specimens housed in PRE that were collected in Namibia. All specimens of higher plants were used in the evaluation. A sizable proportion was georeferenced following the quarter-degree square system of Edwards \& Leistner (1971). Gaps in coverage due to collecting biases and database input errors were corrected where possible (Craven 2002b). The number of species present in each quarter-degree square was calculated and mapped.

Distribution data for endemic species were obtained from the specimen dataset as well as literature sources. Records for endemic species were found in 722 out of over 1200 quarter-degree squares in Namibia. These were variously arranged and mapped: 1 , endemic families, genera and species individually; 2 , the number of endemic species per quarter-degree square; 3 , the number of quarter-degree squares in which species occurred; and 4 , areas where species restricted to only one or two quarter-degree squares were found.

\section{Degree scale}

Quarter-degree squares were chosen for the grid scale in order to show patterns of distribution on as fine a resolution as possible and allowing small or more localized centres of diversity to be apparent. Sufficient information at that scale is available for Namibia and the total area or number of quarter-degree square grids is manageable. Where no or few records were recorded in a quarter-degree square, the grids were 'revisited' and any such 'empty' square individually rechecked and improved. Records from keyword searches and literature sources, i.e. checklists for specific areas such as those of Rodin (1985), Giess \& Snyman (1986), Hines (1992) and Clarke (1999) as well as collections of the first author, were incorporated.

\section{GIS data}

Shapefiles produced in ArcView [Environmental Systems Research Institute (ESRI) 2000] of Namibian features such as soils, topography and rainfall by the AgroEcological Zoning Programme (1996-ongoing) and Atlas of Namibia Project (2002), as well as the positions of important mountains (adapted from Irish 2002) were superimposed onto the grid-based plant data. They were used to draw accurate borders, define localities and help pinpoint possible reasons for the variations in diversity. Profiles showing altitude change across the country that were taken at selected latitudes to cut through various notable topographic features (Atlas of Namibia Project 
2002) were also overlaid. The vertical scales have been exaggerated to highlight the changes in altitude.

The methodology and tables used, and examples of all stages of the process, is described in more detail in Craven (2002b).

\section{Inventory}

The inventory of species endemic to Namibia, taxonomic limits and nomenclature of species follows Craven (1999). The numerous sources for endemic status and updates are listed in Craven (2002b). Genera listed as endemic follow Leistner (2000). Over 600 species (Appendix 1) were investigated and eventually, records for \pm 540 endemic spermatophyte species were available for the analysis and maps. Not all endemics were included in the analysis because endemism in some genera appears inflated due to numerous infraspecific taxa (Maggs et al. 1998), whereas other genera e.g. Crassula (Crassulaceae), Euphorbia (Euphorbiaceae), Salsola (Chenopodiaceae), Tetragonia (Aizoaceae) and some in the family Mesembryanthemaceae need to be revised. Species that are known to occur just over the border of the country were not included, e.g. a number of species in the genus Commiphora (Burseraceae) and family Acanthaceae, particularly the genus Petalidium.

Maps

Arcview (ESRI 2000) was used to produce the maps. Overall species richness and overall endemism could therefore be superimposed to find possible geographical correlation. Similarly, the shapefiles of the \pm 540 species endemic to Namibia for Craven (2002b) were overlaid and the resulting maps scrutinized for congruent patterns. Areas were identified and their species listed, because as
Van Wyk \& Smith (2001) point out, such areas will have their own distinctive complement of species.

Endemic species not included by previous authors were assigned to known centres, i.e. Kaokoveld, Gariep, Waterberg-Otavi and Namibia Central and Southern Highland Centres, where possible. This required looking at locality data of collected specimens for the last two centres, as elements occur at higher elevations or on a specific substrate. The large data set of georeferenced specimens was also used to find subcentres or more localized areas of significance.

\section{RESULTS}

\section{Overall patterns of species richness and endemism}

Species diversity is higher in localities where one vegetation type shifts to another. Variations in altitude and the maximum altitude in any grid are also significantly related to grid diversity (Figure 2). Only two localities in the northeast region can attribute high species richness to high rainfall. Where summer rainfall species overlap with winter rainfall species, however, there is an increase in diversity, e.g. the Rosh Pinah area. Another influencing factor is mist that occurs along the Namibian coast, which may be responsible for more favourable microclimates and increased species richness inland, e.g. the Namukluft near Rosh Pinah and Aus areas.

Namibian endemics were not found in the northeast, which forms part of the Zambezian Domain of White (1983) as this domain continues into countries further north. The southeast is part of the Kalahari Desert, which extends into Botswana, and no endemics were found there because of the general paucity of species and the

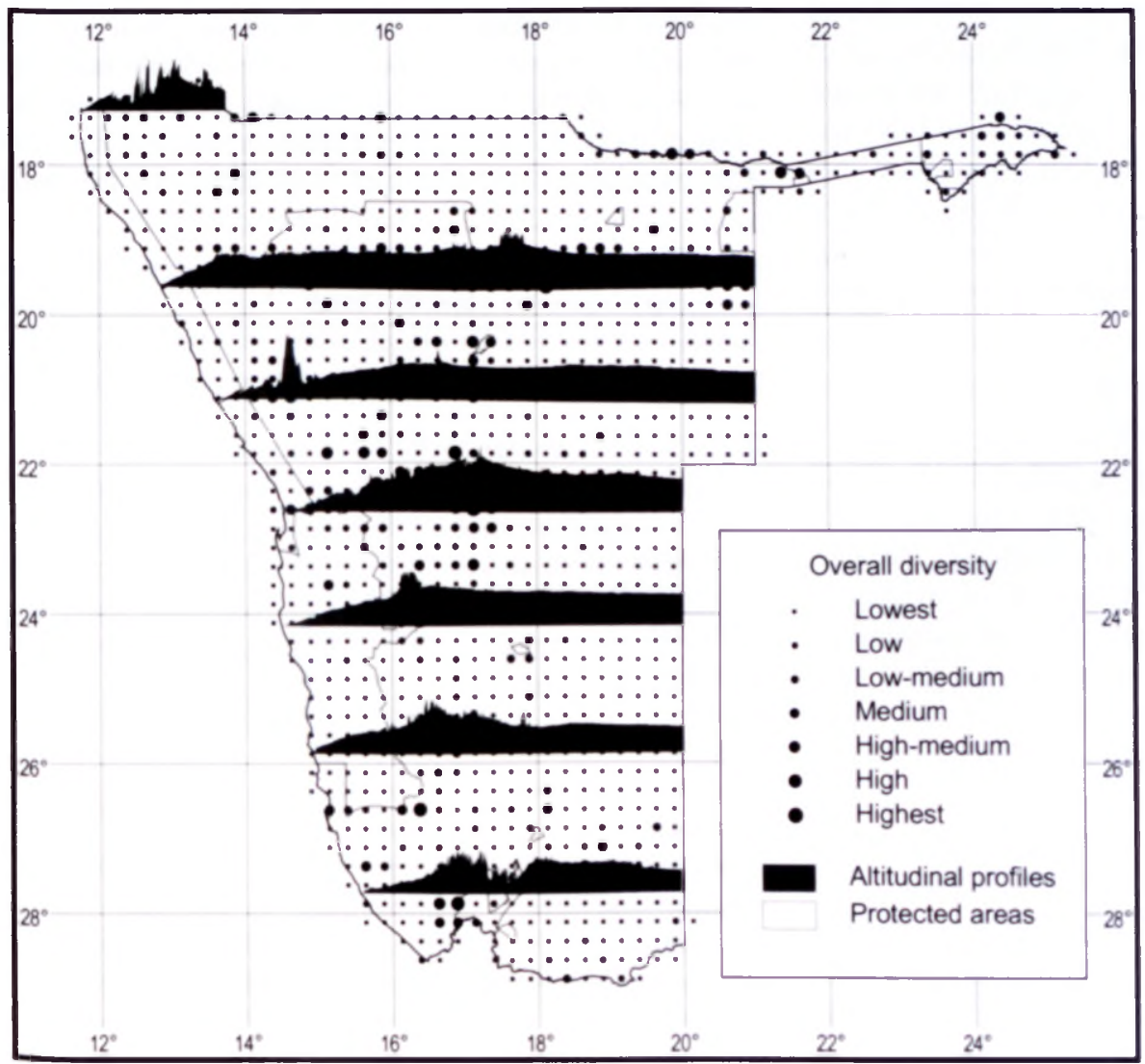

FIGURE 2. Grid-diversity for $\mathrm{Na}$ mibia depicted in five classes with altitude profiles showing correlation between changes in altitude and diversity. 


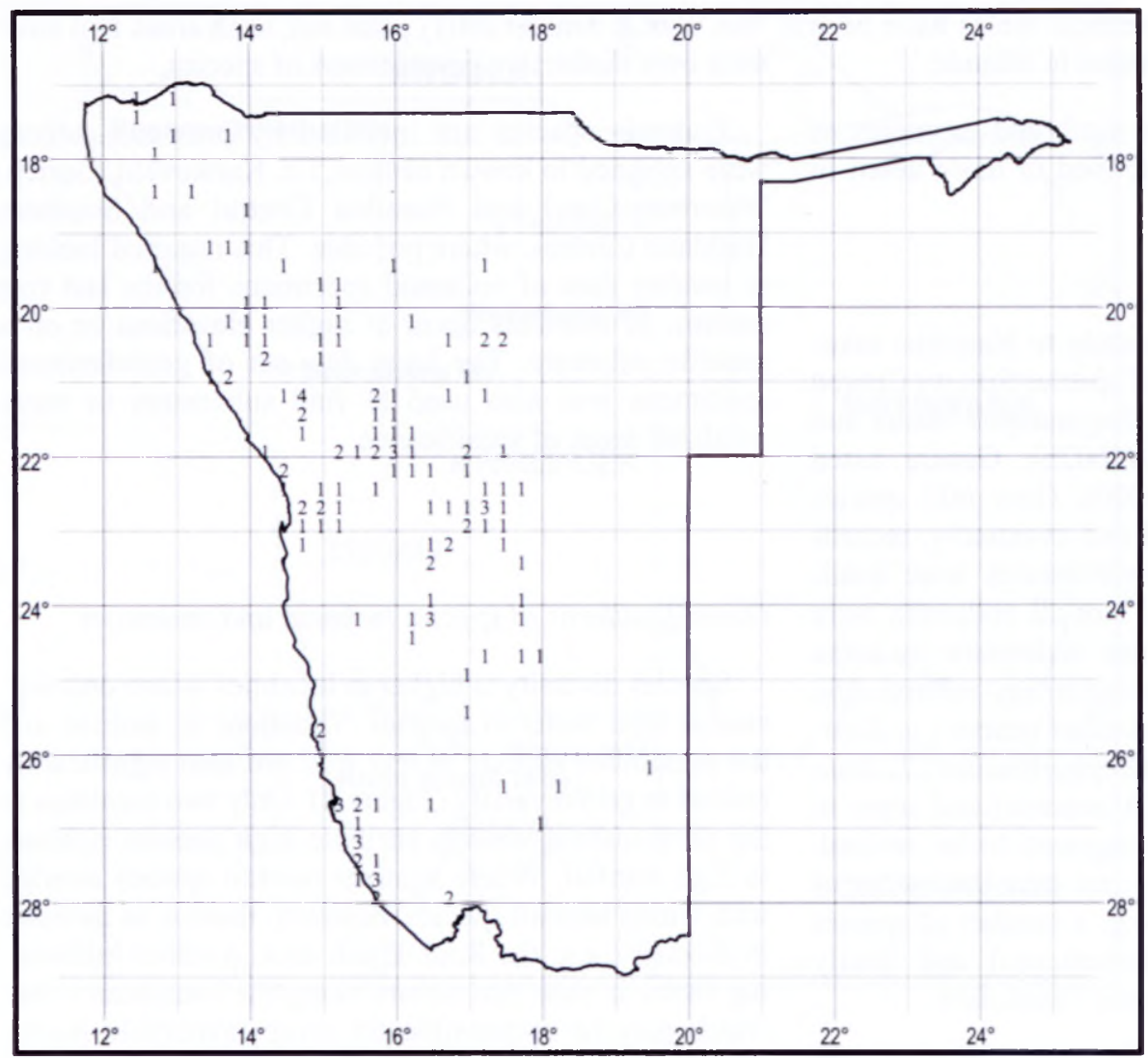

FIGURE 3.-Distribution and number of Namibian endemic genera per quarter-degree grid.

artificial definition of endemic used here. In the rest of Namibia, the map of overall distribution of endemic species does not show any particular spatial pattern. Localities where the quarter-degree squares with the most endemics occur, are often associated with mountains in Namibia. The best example is the Brandberg, which also confirms that endemism increases when mountains are located in deserts. Substrate-specific endemic plants are well known and in Namibia, four Jamesbrittenia species occur only in the limestone of the Waterberg-Otavi area (Hilliard 1994). Hot deserts have very high endemism in spite of their limited flora and vegetation and this has been shown in Namibia by the number of endemic species confined to the Namib (Craven 2002b). ArcView shapefiles for physical features of Namibia, e.g. soils, aspects of climate, did not show marked patterns of similarity at this level of resolution.

Geographical comparison of the overall pattern of diversity and that of endemism, as well as areas of importance for localized endemics and that of overall endemics, show a degree of congruence. Important localized areas however, do not always coincide. Because the count is based purely on the number of species or endemics within that square, areas of richness cannot be distinguished by a particular combination of plant species or endemics. In addition, squares with associated floral elements cannot be identified. Thus a particularly rich area may consist of very widespread species.

\section{Families endemic to Namibia}

There are no families of higher plants restricted to the political borders of Namibia. The most well-known family that occurs only in southwest Angola and Namibia is Welwitschiaceae.

\section{Genera endemic to Namibia}

The natural ranges of sixteen genera fall within Namibia (Figure 3). They are listed in Table 1 with an indication of the number of quarter-degree square grids in which they have been found. With the exception of the genus Ondetia (Asteraceae), most of the endemic genera occur in the central and western parts of Namibia. Arthraerua (Amaranthaceae), Marlothiella (Apiaceae), Eremothammus (Asteraceae), Namibia, Synaptophyllum (Mesembryanthemaceae) and Neoluederitzia (Zygophyllaceae) occur along the coast, whereas Baynesia (Apocynaceae) and Namacodon (Campanulaceae) grow at higher altitudes. Manuleopsis

TABLE 1.-Genera endemic to Namibia and the number of quarterdegree squares in which they occur

\begin{tabular}{llc}
\hline Family & Genus & No. QDS \\
\hline Asteraceae & Onderia & 42 \\
Scrophulariaceae & Manuleopsis & 28 \\
Amaranthaceae & Arthraeria & 18 \\
Poaceae & Kaokochloa & 16 \\
Scrophulariaceae & Chamaegigas & 12 \\
Campanulaceae & Namacodon & 9 \\
Asteraceae & Eremothamnus & 8 \\
Apiaceae & Phlyctidocarpa & 6 \\
Apiaceae & Marloshiella & 5 \\
Mesembryanthemaceae & Sinaptophyllum & 5 \\
Mesembryanthemaceac & Namibia & 3 \\
Apocynaceac & Baynesia & 1 \\
Mesembryanthemaceae & Jensenohorna & 1 \\
Mesembryanthemaceac & Ruschianthus & 1 \\
Scrophulariaceae & Dintera & 1 \\
Zygophyllaceac & Neoluederitaia & 1 \\
\hline
\end{tabular}

QDS. quarter-degree square 


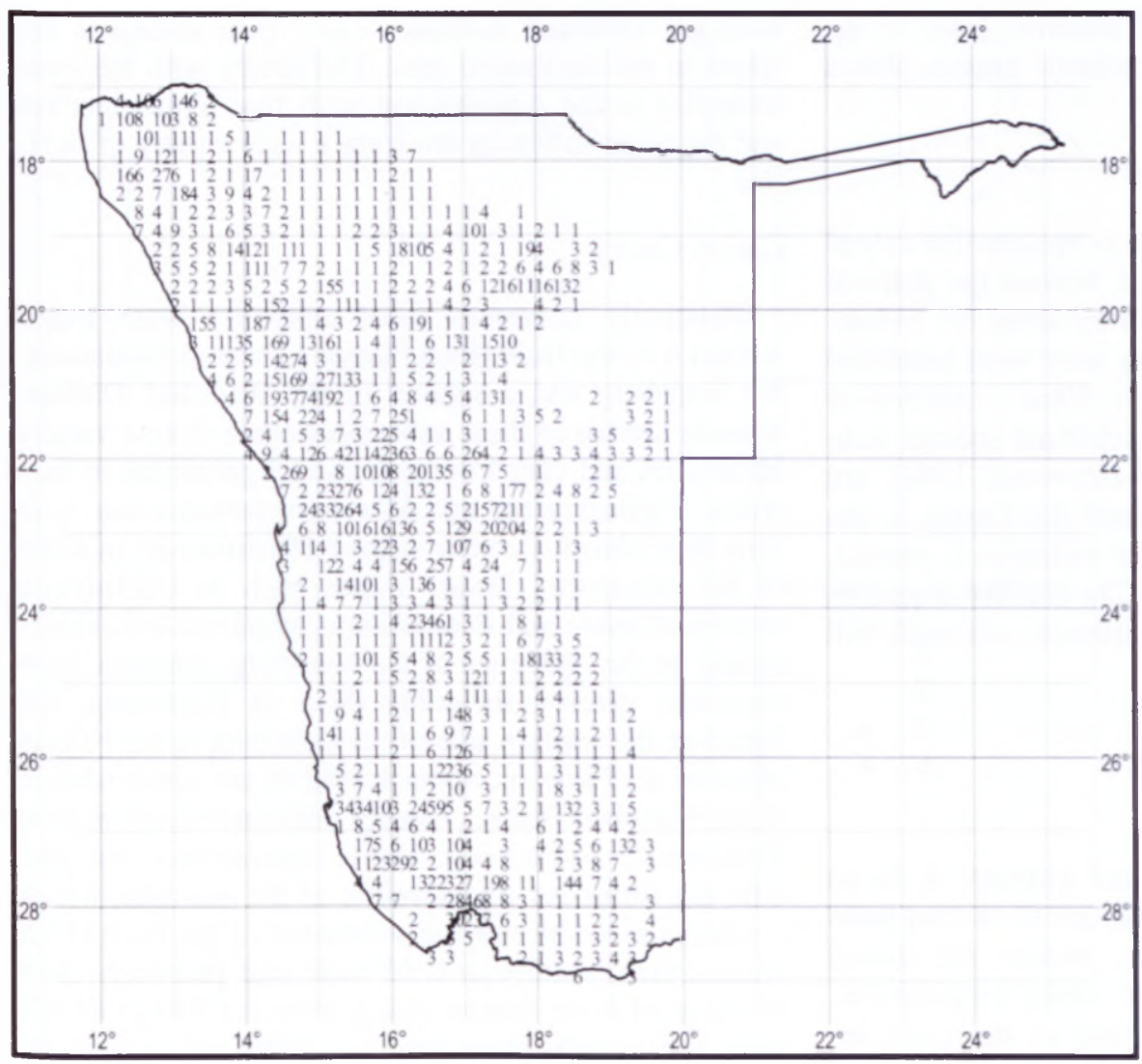

FIGURE 4.-Distribution and number of Namibian endemic species per quarter-degree grid.

(Scrophulariaceae) is fairly widespread, but generally found on higher ground. Chamaegigas (Scrophulariaceae) is a hydrophyte that inhabits pools in granite outcrops in central Namibia.

All four genera in family Mesembryanthemaceae occur in the winter rainfall region of southwest Namibia. Family Apiaceae, with two endemic genera, is of particular interest as it has very few representatives in species and number of individuals in Namibia. A recently described genus, Baynesia (Bruyns 2000), attests to the fact that new genera may still be described in Namibia, especially in certain families that require revision, e.g. Mesembryanthemaceae. Ondetia occurs close to Botswana and may eventually be found there (Craven \& Klaassen 1998). It is very closely related to Geigeria (which is presently under revision) and often mistaken for a Geigeria species in the field.

There are also four near-endemic genera, i.e. they occur in Namibia and southwestern Angola, namely Antiphiona (Asteraceae), Marcelliopsis (Amaranthaceae), and Welwitschia (Welwitschiaceae). Volkiella (Cyperaceae) has been recorded once in Zambia. Ruschianthemum (Mesembryanthemaceae), which occurs just over the border in the northern Cape, has been included in Stoeberia (Chesselet \& Van Wyk 2002).

\section{Species endemic to Namibia}

Approximately 600 of the nearly 4000 indigenous species recorded for Namibia are considered endemic to within the borders of the country (Figure 4) and are found in many different families and genera; 62 of the 157 families in Namibia have endemic species, whereas 231 genera out of 958 genera have endemic species.
The most important families are the Mesembryanthemaceae, Asteraceae and Acanthaceae. The genera Aloe (Asphodelaceae), Euphorbia (Euphorbiaceae), Hermannia (Sterculiaceae), Jamesbrittenia (Scrophulariaceae), Petalidium (Acanthaceae), Salsola (Crassulaceae), Stipagrostis, Eragrostis (Poaceae) and Zygophyllum (Zygophyllaceae) have the most endemic species besides Conophytum and Lithops (Mesembryanthemaceae), which have numerous infraspecific taxa. Distributions of about 600 endemic species and certain families and genera are mapped in Craven (2002b). Two examples showing distinctive patterns are illustrated here. Family Mesembryanthemaceae (Figure 5) is mainly restricted to the southwestern corner of Namibia which is also the only area with winter rainfall. Figure 6 shows endemism in Commiphora which occurs more commonly in the north with few plants in the winter rainfall zone. Some species have very widespread distributions and are well represented in the collection, whereas others are limited to one locality and one collection. One endemic was recorded in 195 different quarter-degree squares, and nine quarter-degree squares had more than 40 endemics. The quarter-degree square with the highest number of species were tabulated (Table 2) and the grid in which the Brandberg occurs is shown to have the most endemic species, followed by the Windhoek area.

Species endemic to localized areas are found mainly in western Namibia, but also in the central regions associated with high elevations. A number of localities were found to house four or more very restricted-range species.

The dominant life form of the endemics of the southwest winter rainfall region is succulents, whereas further inland, i.e. east of the Hunsberg, dwarf shrubs are more 
common. The only region with endemic trees is the Kaokoveld. The distribution of endemic grasses shows them to be widespread.

\section{Namibian near-endemic species}

Near-endemics are defined here as species that extend marginally into another region, i.e. beyond the political borders of Namibia. Two noteworthy areas for endemics and near-endemics in Namibia have been identified under the auspices of the IUCN Plant Conservation Programme. These centres of exceptional species richness and endemism (Davis \& Heywood 1994) are the Kaokoveld in the northwest and the Gariep in the southwest. Further analysis of near-endemics is needed, including the species in this study. The number of species per quarter-degree square in the northwest and south will be higher.

\section{Taxon phvtogeographic centres}

\section{Kaokoveld Centre}

Considering the topography and climate, it is no wonder that mapped plant distributions show two main subregions besides the Brandberg, namely the coastal strip, which is affected by fog and cooler temperatures, and the inland highlands. Endemics of the coast include Ectadium rotundifolium, Merremia multisecta, Hermannia gariepina and grasses such as Chloris flabellata and Sporobolus virginicus. Most of the endemic taxa occurring on the highlands will not be found on the coastal plains. They are more numerous and often confined to mountainous areas.

Subcentres of importance are the Baynes Mountains and the area around Sanitatis and Orupembe. Both areas have six localized endemics each. Four endemics are found in the Sesfontein area. The family with the most endemics is the Acanthaceae with five representatives and the other endemics are from a wide variety of families.

\section{Gariep Centre}

Relatively numerous local endemics were found around Aus, the Huib Hoch Plateau to Namus Mountains, the Hunsberg and a section of the Warmbad District. Species limited to these subcentres come from a variety of families and vary from grasses and geophytes to succulent Euphorbiaceae and Mesembryanthemaceae. Life form type shows a certain degree of uniformity in some of the subcentres. Dwarf shrubs such as Caesalpinia merxmuellerana and Petalidium cymbiforme are characteristic of the endemics of the Hunsberg, whereas more succulent species, including three in Euphorbia, are found on the western side of the Hunsberg in the Numas Mountains. Three succulent mesembs are also endemic to the Warmbad District, namely Antimima eendornensis, Schwantesia constanceae and $S$. succumbens. No specific life forms are characteristic of the Aus area, which is characterized by varying substrates, or the Huib Hoch Plateau areas. Although field work will probably result in many of these species being recorded further afield, some conspicuous plants such as Caesalpinia merxmuellerana and Zygophyllum giessii have not been found to be widespread despite intense searching.

\section{Waterberg-Otavi Centre}

Additional species restricted to this centre identified here, but not necessarily only occurring on limestone, are Heteromorpha papillosa (Apiaceae), Pentatrichia avasmontana (Asteraceae), Plectranthus dinteri (Lamiaceae)

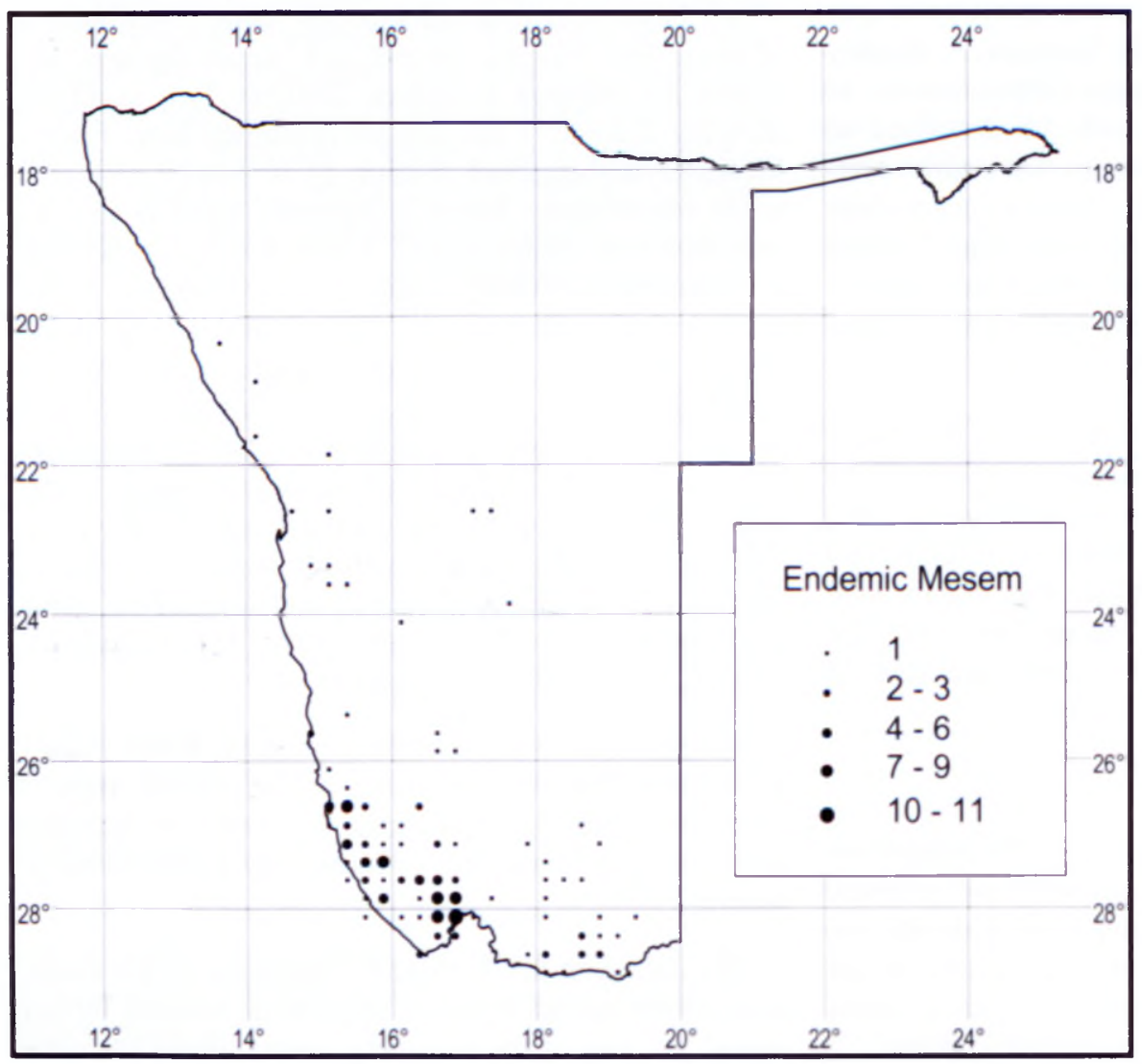

FIGURE 5-Distribution of endemic plants in Mesembryanthemaceac and diversity per quarter-degree grid. 


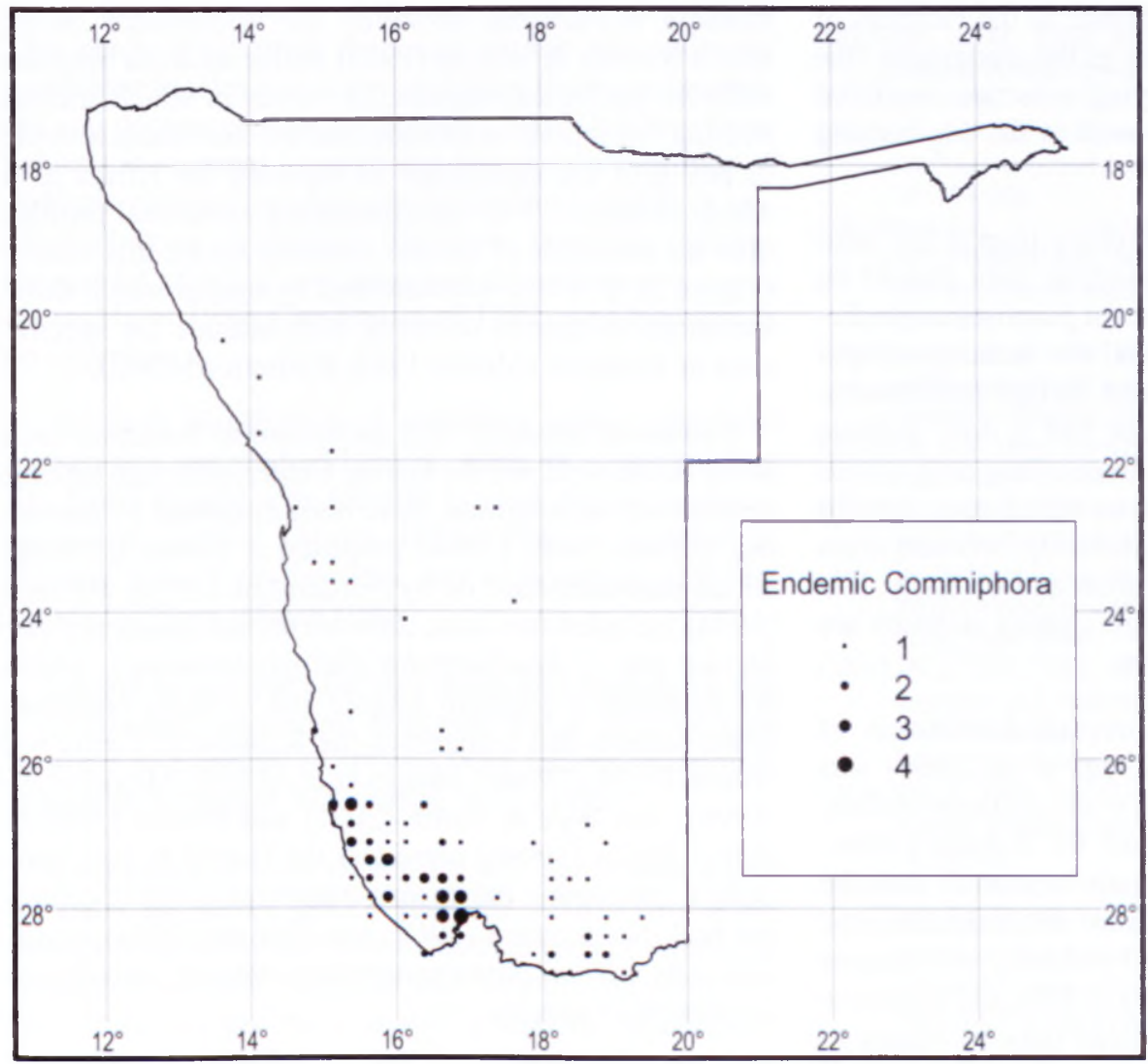

FIGURE 6.-Distribution of endemic plants in Commiphora and diversity per quarter-degree grid.

which is also in the Windhoek region, and Thesium xerophyticum (Santalaceae) also on the Gamsberg. In addition, Thesium is in need of revision and although both the genera Plectranthus and Heteromorpha have been revised, little or no field work was carried out in Namibia. Pentatrichia is presently under revision. Species reported to date only from the Waterberg are Dintera pterocaulis (Scrophulariaceae), Eriospermum citrimum and E. lavranosii (Eriospermaceae).

\section{Central Namibia and Southern Highland Centre}

Fifteen Manuleae (Scrophulariaceae) were found to occur in a highland centre (Hilliard 1994) that included the Brandberg. Erongo, Khomashochland, Auas, Gamsberg. Naukluft, Tiras, Karasberg and surrounding high ground, usually above $\pm 900 \mathrm{~m}$. It excludes the limestone area of the Waterberg, but may stretch into Botswana. An analysis of mapped endemics and habitat data show that numerous range-restricted species are confined to higher elevations, as prescribed by the definition of this centre by Hilliard (1994). The floristic elements range from shrubs (Nicotiana africana) and dwarf shrubs (Corchorus merxmuelleri. Hermannia merxmuelleri) to geophytes (Haemanthus avasmontanus. Lapeirousia avamontana) with a few very localized succulents (Ebracteola montis-moltkei, Euphorbia monteiroi subsp. brandhergensis, Aloe viridiflora).

\section{DISCUSSION}

Numerous hypotheses have been proposed to explain patterns of species diversity (Schmida \& Wilson 1985), but none have been found to apply well to all bodies of data. Underlying datasets and resolution can also result in different patterns of diversity. This is seen when
Namibia is mapped continentally (Mutke et al. 2001), regionally (Rebelo 1994) or nationally (Maggs et al. 1994). In spite of the finer resolution used here, the most species-rich areas in Namibia do not differ much from those first indicated (Maggs et al. 1994). The differences lie in better definition of the boundaries, additional localities and important smaller localities. Examples are the Naukluft. Windhoek and Aus regions. The inclusion of the Naukluft as an important area by Maggs et al. (1994) was suspected to be an artifact of high collecting intensity and this was proved here to be the case. On the other hand. species richness in the Windhoek area is not necessarily an artifact of good collecting. despite being close to a high population of potential collectors. It includes the second highest mountain in Namibia (Irish 2002), and a number of grasses (Klaassen \& Craven 2003), and other species that are not known from elsewhere in Namibia are found here. It indicates that this flora includes outliers from more distant areas and is in agreement with Major (1988), who considers mountains to be mesic refugial islands, which form ideal refuges in times of climate change. Another area of high diversity, near Aus, housed a concentration camp during World War II where the interned German citizens botanized to

TABLE 2-Quarter-degree squares (QDS) with the most endemic species recorded

\begin{tabular}{lll}
\hline QDS & Locality & $\begin{array}{l}\text { No. } \\
\text { endemic } \\
\text { spp. }\end{array}$ \\
\hline 2114BA & Brandberg area & 74 \\
$2217 \mathrm{CA}$ & Windhock Auas Mtn area & 63 \\
$2616 \mathrm{CB}$ & Region around town of Aus & 55 \\
$2416 \mathrm{AB}$ & East of Naukluft Mtns Farm Bullspoon & 49 \\
$2716 \mathrm{DD}$ & Namuskluft Farm. Namus Mtns & 43 \\
\hline
\end{tabular}


pass the time. Factors that contribute to the richness of this area include the diverse nature of the topography (the start of the escarpment) and varying substrate (scattered granite outcrops in the area) as well as the fog coming inland from the coast.

Although the plant species diversity map is the most detailed map of its kind for Namibia, care should be taken before using it for management purposes or predictions. Both the delimited areas and the numbers of species predicted for the regions need further refinements. Two aspects of conservation value that it does indicate are: 1, that many areas are more diverse than may appear during periods of harsh conditions, which may last for years or decades; and 2, the relationship between areas set aside as formal conservation areas and diversity. It is apparent that certain areas of high species richness are not afforded any formal protection.

The first map to show the overall distribution of endemic species in Namibia (Maggs et al. 1994) was based on 145 species. Endemics of southern Africa, including Namibia, were mapped by Rebelo (1994). Differences between the latter map (regional) and the present one for Namibia (national) are noticeable because of the scale, definition of the word endemic, and datasets used. Maps published in Simmons (1998) and Simmons et al. (1998) were based on updated data in Maggs et al. (1997) using half-degree squares, because according to Simmons et al. (1998), bird data show that this scale reduces collecting bias. The results presented here justify the use of quarter-degree, because working on a national level, more quality control of the data is possible and other sources such as literature, field work and shapefiles of physical features can be used. An undefined 'escarpment' area was said to be the main centre for endemic plants by Simmons et al. (1998). Overlaying a defined escarpment developed by the Atlas of Namibia Project (2002) onto the endemic data indicates that this is only partially correct. Although there is an association between increased numbers of endemic species and the escarpment, the area between the northern and southern escarpments also show localities of importance, not only in general, but also for those with limited ranges.

The maps resulting from this study are published by the Atlas of Namibia Project (2002), where they are also combined with maps of Namibian fauna. Mendelsohn et al. (2002) conclude that the most notable zones of high diversity for fauna and flora occur in the northeast, in the Karstveld around Tsumeb, in highland areas in the centre of Namibia, and in various scattered areas of higher ground further west. Plant endemism was also combined with that of animals, and Mendelsohn et al. (2002) conclude that the overall patterns of endemism in Namibia are quite different from those of overall diversity. The greatest majority of endemics are found in the dry, western and northwestern regions of Namibia. On a regional scale of plants only (and lower resolution), Rebelo (1994) reports a stronger correlation between species richness and endemicity.

Namibian endemic plants, as in other parts of the world, are usually associated with altitude, substrate. or variations in geography, which provide numerous microhabitats. The most important areas for species richness in Namibia, however, are 'transitional' areas, which Shmida \& Wilson (1985) define as areas between different ecological regions, i.e. zones in which species overlap. Variations in altitude and the maximum altitude in any grid are significant as reported for Africa as a whole (Linder 1999). Superimposing altitudinal profiles onto the shapefile of species richness shows this clearly (Figure 2). It is also substantiated by studies which show variations in species diversity with altitude for specific sites or localities (Moisel 1982; Rutherford 1992).

Centres of diversity and endemism in Namibia, such as the Kaokoveld and the Gariep Centre, although lacking consistency in definition, have been discussed by numerous authors. Volk (1964) proposed a Kaoko Element, which was elaborated on by Nordenstam (1974). Hilliard (1994) included two taxa, Jamesbrittenia canescens var. laevior and $J$. heucherifolia (Scrophulariaceae), which are confined to southern Angola and northern Namibia. Other authors that recognized the Kaokoveld Centre are Hilton-Taylor (1994a), Maggs et al. (1994), Maggs et al. (1998), Van Wyk \& Smith (2001) and Craven (2002a). Hilton Taylor (1994b) considers the Gariep to be essentially a geographic rather than a phytogeographic centre, but both Nordenstam (1969) and Hilliard (1994) recognize it as a taxon phytogeographic centre of importance for numerous species.

Mapping all Namibian endemics has shown that the distributions of many elements need to be reassessed. Species presently regarded as e.g. Kaokoveld elements, (Welwitschia mirabilis, Acanthosicvos horridus, Cyphostemma currorii, Acacia robynsiana and Moringa ovalifolia) may stretch far beyond what is generally regarded as the centre. Another example is the Brandberg, which is considered an outlier of the Kaokoveld Centre by Nordenstam (1974) and Hilton Taylor (1994a). Provisional results of the floristic elements of the Brandberg (Craven \& Craven 2000) show that numerous range-restricted species also occur on other highlands further south and it is rather a part of the Highland Centre as suggested by Hilliard (1994).

The Kaokoveld and the Gariep Centres are basically geographic regions, so inclusion of species within the centres was based on presence or absence in the area. This is not possible with the Namibia Central and Southern Highland Centre and the Waterberg-Otavi Centre as they are identified by determinants such as habitat or substrate specificity. These centres do not show a clear geographic pattern of distribution on a map until altitude contours or outlines of mountains are included. More endemic species will probably be included in these centres once more is known about such habitat requirements.

The name, Gariep, has also been used in large-scale mapping by Jürgens (1991) despite a different approach, i.e. including life form and climate in the analyses. Such approaches must not be confused with that of taxon phytogeography as discussed here.

In general, the variable nature of most aspects of Namibia's rainfall, as well as the paucity of overall climatic data. precludes using climate at this level of resolution. It is, however, true to say that Namibia differs from Africa as a whole, because the most species-rich areas 
are in the wetter parts of the continent (Linder 1999). This study highlighted the need for the microclimatic conditions in which so many endemics thrive, to be studied and documented in a systematic way. Defining these habitats is essential to understanding the distributions of endemic plants. The same can be said for peculiar or isolated substrata (serpentine, limestone, quartzite, calcareous sands) which is a widespread phenomenon in some areas (Major 1988; Cowling et al. 1992), and Namibia is no exception.

Although distribution of endemics among life form classes was not studied here in detail, it is evident that life forms change with locality as recorded for endemic species in general (Major 1988). This is ascribed to climate, history of the flora and competition with the associated flora (Major 1988).

Certain taxa require floristic study and field work, but a provisional assessment suggests that a locality may be home to a variety of species from various taxonomic groups as suggested by Cowling et al. (1992).

Knowledge of local endemism will help create a better basis for future policy (Brenan 1978). This study does provide sufficient information on certain aspects of Namibia's endemic plants to start formulating conservation strategies, but there is still a need for satisfactory taxonomic knowledge as well as more distribution data. It is also imperative that the information is used correctly. Simmons et al. (1998) concluded that another $11 \%$ of the land area would be required to protect Namibia's endemic plants. If the endemic plants already found within protected areas had been removed from the dataset prior to the analysis, the resulting value would be much lower. No matter how highly a species is regarded, as soon as it is adequately conserved, it is no longer used as an argument to conserve another area (Kirkpatrick 1983). Because species are not spread evenly around the world and unique concentrations may occur in relatively small areas, i.e. within the political borders of a country like Namibia, the onus is on Namibia to protect these species.

\section{ACKNOWLFDGEMENTS}

The National Herbarium of Namibia, especially the database manager, Esmerialda Klaassen are thanked for the use of SPMNDB. John Mendelsohn and the Atlas team are also thanked for the final maps on diversity and endemism produced for the Atlas of Namibia. The AgroEcological Zoning Programme is thanked for the use of shapefiles. The unpublished plant lists of Craig HiltonTaylor for the Kaokoveld and Gariep Centres is greatly appreciated. The contribution made by SABONET, i.e. the database and funding for further study, is greatly appreciated.

\section{REFERFNCES}

AGRO-ECOLOGICAL ZONING PROGRAMME. 1996-ongoing Directorate of Agricultural Research and Training. Ministry of Agriculture, Windheck

ATL.AS OF NAMIBIA PROJECT. 2(0)2. Directorate of Fnvironmental Affairs. Ministry of Environment and Tourism. Windhock http:/ www.dea.met.gov.na.

BRENAN, J.P.M. 1978. Some aspects of the phytogeography of tropical Africa. Annals of the Missouri Botanical Garden 65: $437-478$.

BRUYNS. P.V. 2000. Bannesia, a new genus of stapeliad from the northwestem-most comer of Namibia (Apocynaceae). Novon 10: $354-358$

CALDECOTT, J.O., JENKINS, M.D., JOHNSON, T.H. \& GROOMBRIDGE, B. 1996. Priorities for conserving global species richness and endemism. Biodiverity \& Conservation 5 : 699-727.

CHESSELET. P. \& VAN WYK. A.E. 2002. Mesembs with nut-like schizocarpic fruit and Ruschianthemum Friedrich sunk under Stoeberia. Bothalia 32: 187-190.

CLARKE. N.V. 1999. Flora of the Cuvelai wetlands, northem Namibia. Cimbebasia 15: 99-115.

COWLING, R.M. GIBBS RUSSELL. G.E. HOFFMAN, M.T \& HILTON-TAYLOR, C. 1989. Pattems of plant species diversity in southern Africa. In B.J. Huntley. Biotic diversin in southern Africa: concepts and conservation: 19-50. Oxford University Press, Cape Town.

COWLING, R.M. HOLMES, P.M. \& REBELO, A.G. 1992. Plant diversity and endemism. In R.M. Cowling. The ecology of finbos: nutrients, fire and diversity: 62-112. Oxford University Press. Cape Town.

CRAVEN, P. 1999. Checklist of Namibian plant species. Southem African Botanical Diversity Network Report No. 7. SABONET, Windhoek

CRAVEN, P. 2002a. Plant species diversity in the Kaokoveld, Namibia. In M. Bollig. E. Brunotte \& T. Becker, KaokolandInterdisziplinäre Perspektiven zu Kultur-und Landschaftswandel im ariden und semi-ariden Nordwesten Namibias: 75-80. Kölner Geographische Arbeiten 77, Cologne.

CRAVEN. P. 2002b. Phvtogeography of the Namibian Nora: a taxon approach. M.Sc. thesis, University of Stellenbosch, Stellenbosch

CRAVEN. P. \& CRAVEN, D. 2000. The flora of the Brandberg. Namibia. In A.H. Kirk-Sprigs \& E. Marais. Biodiversity of the Brandberg Massif. Namibia. Cimbebasia Memoir 9: 49-67.

CRAVEN, P. \& KLAASSEN, E. 1998. Onderia, the problematic cousin of vermeerbos. Spotlight on Agriculture. Ministry of Agriculture. Water and Rural Development. Windhoek.

DAVIS, S.D. \& HEYWOOD. V.H. 1994. Centres of plant diversity a guide and strategv for their conservation. Oxford University Press. Oxford.

EDWARDS, D. \& LEISTNER, O.A. 1971. A degree reference system for citing biological records in South Africa. Mirteilungen aus der Botanischen Staatssammlung. München 10:501-509.

ENVIRONMENTAL SYSTEMS RESEARCH INSTITUTE (ESRI) 2000. Archiew 3.2a Sofrware. Redlands. USA.

GIBBS RUSSELL. G.E. 1985. Analysis of the size and composition of the southern African flora. Bothalia 15: 613-629.

GIBBS RUSSELL. G.E. 1987. Preliminary floristic analysis of the major biomes in southem Africa. Bothalia 17: 213-227.

GIESS, W. \& SNYMAN, J.W. 1986. The naming and utilization of plant life by the Zu'hoasi Bushmen of the Kau-Kauveld. In R. Vossen \& K. Keuthmann. Contemporany studies on Khoisan 1 : 237-246.

GOLDBLATT, P 1978. An analysis of the flora of southern Africa: its characteristics, relationships and origins. Annals of the Missouri Botanical Garden 65: $369-36$.

HILLIARD. O.M. 1994. The Manuleae A tribe of Scrophulariaceae. Edinburgh University Press. Edinburgh.

HILTON-TAYLOR, C. 1994a. Centres of plant diversity: Karoo-Namib region: the Kaokoveld. In S.D. Davis \& V.H. Hevwood. Centres of plant diversin: a guide and strategy for their conservation. 201-203. Oxford University Press. Oxford

HILTON-TAYLOR. C. 1994b. Centres of plant diversity: Karoo-Namib region: Westem Cape domain (Succulent Karoo). In S.D. Davis \& V.H. Hevwood. Centres of plant diversity: a guide and stratexy for their consenation: 204-217. Oxford University Press. Oxford.

HINES, C.J.H. 1992. An ecological stuch of the vegetation of eastern Bushmanland (Namibia) and its implications for development M.Sc. thesis. Instutute of Natural Resources. University of Natal. Pietermaritzburg.

IRISH, J. 2002. Namibian mountains: hiodiversin potential hased on topography. Report for the Mountain Ecosytem Working Group of the National Biodiversity Task Force. Windhoek. 
JÜRGENS, N. 1991. A new approach to the Namib region. I Phytogeographic subdivision. Vegetatio 97: 21-38.

KIRKPATRICK, J.B. 1983. An iterative method for establishing priorities for the selection of nature reserves: an example from Tasmania. Biological Conservation 25: 127-134.

KLAASSEN, E. \& CRAVEN, P. 2003. Checklist of grasses in Namibia. Southern African Botanical Diversity Network Report No. 20. SABONET, Pretoria \& Windhoek.

LEISTNER, O.A. (ed.). 2000. Seed plants of southern Africa: families and genera. Strelitzia 10. National Botanical Institute. Pretoria.

LINDER. H.P. 1999. Phytogeography of African plants-symposium overview. In J. Timberlake \& S. Kativu. African plants: biodiversity, taxonomy and uses: 129. Proceedings of the 1997 AETFAT Congress Harare, Zimbabwe. Royal Botanic Gardens, Kew

LINDER, H.P. 2001. Plant diversity and endemism in sub-Saharan tropical Africa. Journal of Biogeography 28: 169-182

MAGGS, G.L. 1998. Plant diversity in Namibia. In P. Bamard. Biological diversity in Namibia: a country study: 116-122. The Namibian National Biodiversity Task Force. Windhoek.

MAGGS, G.L., CRAVEN, P. \& KOLBERG, H.H. 1998. Plant species richness, endemism and genetic resources in Namibia Biodiversity \& Consenvation 7: 435-446.

MAGGS, G.L., CRAVEN, P., KUBIRSKE, R., KLAASSEN, E.S. MANNHEIMER, C.A. \& UIRAS, M.M. 1997. Flora of Namibia. Report for the Annual Research Reporting Conference. Ministry of Agriculture, Water and Rural Development, Windhoek.

MAGGS, G.L., KOLBERG, H.H. \& HINES, C.J.H. 1994. Botanical diversity in Namibia - an overview. In B.J. Huntley, Botanica diversity in southern Africa. Strelitzia 1: 93-104. National Botanical Institute, Pretoria.

MAJOR, J. 1988. Endemism: a botanical perspective. In A.A. Myers \& P.S. Giller, Analytical biogeography: An integrated approach to the study of animal and plant distributions: 117-146. Chapman \& Hall. London.

MENDELSOHN, J., JARVIS, A., ROBERTS, C. \& ROBERTSON, A 2002. Atlas of Namibia: a portrait of the land and its people. David Phillip Publishers, Cape Town

MERXMÜLLER. H. (ed.). 1966-1972. Prodromus einer Flora von Südwestafrika. Cramer, Lehre.

MOISEL, L. 1982. Wanderungen im Brandbergmassiv. Dinteria 16
$21-26$

MUTKE, J., KIER, G., BRAUN, G., SCHULTZ, C. \& BARTHLOTT, W. 2001. Patterns of African vascular plant diversity - a GISbased analysis. Systematic Geography of Plants 71: 11251136.

NORDENSTAM. B. 1969. Phytogeography of the genus Eunyops (Compositae). Opera Botanica 23: 1-77.

NORDENSTAM, B. 1974. The flora of the Brandberg. Dinteria 11 $3-67$.

REBELO, A.G. 1994. Iterative selection procedures: centres of endemism and optimal placement of reserves. In B.J. Huntley, Botanical diversity in southern Africa. Strelitzia 1: 231-257. National Botanical Institute. Pretoria.

RODIN, R.J. 1985. The ethnobotany of the Kwanyama Ovambos. Monographs in Systematic Botany 9: 1-165.

RUTHERFORD. M.C. 1992. Notes on the flora and vegetation of the Omuverume Plateau-Mountain. Waterberg. South West Africa. Dinteria 8: 3-55.

SCHMIDA, A. \& WILSON, M.V. 1985. Biological determinants of species diversity. Journal of. Biogeography 12: 1-20.

SIMMONS, R.E. 1998. Areas of high species endemism. In P. Bamard. Biological diversity in Namibia: a country studt: 72-74. The Namibian National Biodiversity Task Force, Windhoek

SIMMONS, R.E., GRIFFIN, M GRIFFIN, R.E. MARAIS, E. \& KOLBERG, H. 1998. Endemism in Namibia: patterns, processes and predictions. Biodiversity \& Conservation 7: 513-530

STOTT. P. 1981. Historical plant geography: an introduction. Allen \& Unwin, London.

VAN WYK, A.E \& SMITH, G.F. 2001. Regions of floristic endemism in southern Africa. A review with emphasis on succulents. Umdaus Press, Pretoria.

VOLK, O.H 1964. Die afro-meridionale-occidentale Floren-Region in Südwestafrika. Beiträge zur Phytologie zu Ehren Prof. $H$ Walters 65 Geburtatages. Ulmar. Stuttgart.

WEIMARCK, H. 1941. Phytogeographical groups, centres and intervals within the Cape tlora. Lunds Universitets Arsskrift N.F.Afd. 2.37: $1-143$

WHITE, F. 1983. The vegetation of Africa: a descriptive memoir to accompany the UNESCOAERFAT/UNSO vegetation map of Africa. United Nations Educational Scientific Cultural Organization, Paris.

\section{APPENDIX 1.- List of Namibian endemic plants used in the evaluation}

$=$ Species name in italics indicates a synonym used in the original evaluation.

* Endemic species not used in the evaluation due to lack of data or species described since the evaluation.

- Species that have been collected outside Namibia since the evaluation. Unless otherwise stated, species indicated by $\bullet$ are near-endemic and mainly based on collections of Craven or Bruyns, particularly from Angola.

\author{
Acanthaceae \\ Barleria \\ -damarensis T.Anderson \\ dinteri Oberm. \\ jubata S.Moore \\ kaloxytona Lindau \\ lanceolata (Schinz) Oberm. \\ meeuseana P.G.Mev: \\ merxmuelleri P.G.Me \\ solitaria P.G.Me \\ Blepharis \\ ferox P.G.Mev: \\ fleckii P.G.Mey: \\ gigantea Oberm \\ meyeri Vollesen \\ pruinosa Engl. \\ spinifex Merxm \\ Hygrophila gracillima (Schinz) Burkill \\ Justicia \\ cuneata $\mathrm{Vah} /$ subsp. hoerleiniana (P.G.Mey.) Immelman \\ guerkeana Schinz \\ -platysepala (S.Moore) P.G.Mey \\ Monechma \\ calcaratum Schin: \\ callothamnum Mundan \\ crassiusculum P.G.Mev \\ desertorum (Engl.) C. B.Clarke
}

grandiflorum Schin:

leucoderme (Schinz) C.B.Clarke

serotinum $P G$ Mey.

tonsum P.G.Mel

Peristrophe

grandibracteata Lindau

hereroensis (Schinz) K. Bulkwill

namibiensis $K$ Balkwill

subsp. brandbergensis $K$ Balkwill

subsp. namibiensis

Petalidium

canescens (Engl.) C. B.Clarke

cymbiforme Schinz

giessii P.G.Me

lanatum (Engl.) C.B.Clarke

linifolium T.Anderson

luteo-album A.Meeuse

* ohopohense P.G.Mey

pilosi-bracteolatum Merrm \& Hainz

ramulosum Schin:

rautanenii Schins

subcrispum P.G.Mey

Rhimacanthus kaokoensis K Balkwill \& S Williumson

Ruellia

aspera (Schinz) E.Phillips

brandbergensis Kers 


\section{Aizoaceae}

Aizoanthemum

dinteri (Schinz) Friedrich

galenioides (Fenzl ex Sond.) Friedrich

rehmannii (Schinz) H.E.K.Hartmann = Aizoanthemum membrumconnectens Dinter ex Friedrich

Aizoon giessii Friedrich

Tetragonia

rangeana Engl.

-schenckii (Schinz) Engl

Trianthema hereroensis Schinz

\section{Alliaceae}

Tulbaghia calcarea Engl. \& K.Krause, insuff. known

\section{Amaranthaceae}

Arthraerua leubnitziae (Kuntze) Schinz

Calicorema squarrosa (Schinz) Schinz

Hermbstaedtia spathulifolia (Engl.) Baker

Marcelliopsis splendens (Schinz) Schinz

\section{Amaryllidaceae}

Ammocharis nerinoides (Baker) Lehmiller

\section{Crinum}

paludosum $I$. Verd.

rautanenianum Schin

Haemanthus avasmontanus Dinter

* Namaquanula bruynsii Snijman

* Nerine pusilla Dinter

Strumaria

hardyana D.Müll.-Doblies \& U.Müll.-Doblies phonolithica Dinter

\section{Anacardiaceae}

Rhus

problematodes Merxm. \& Roessler

volkii Suess.

\section{Apiaceae}

Anginon streyi (Merxm.) I.Allison \& B-E.van Wik

Heteromorpha papillosa C.C.Touns.

Marlothiella gummifera $H$.Wolff

Phlyctidocarpa flava Cannon \& W.L.Theoh

Polemanniopsis sp. = Merxmuller \& Giess 32010

\section{Apocynaceae}

-Australluma peschii = Caralluma peschii $\mathrm{Ne}$

Baynesia lophophora Bruyns

Brachystelma

blepharanthera H.Huher

codonanthum Bruins

recurvatum Bruyns

schinzii (K.Schum.) N.E.Br

schultzei (Schlir.) Bruin

- Ceropegia dinteri Schlir.

Cynanchum meyeri (Decne.) Schlst.

Ectadium

latifolium (Schinz) N.E.Br.

rotundifolium (H.Huher) Venter \& Kotze

- Comphocarpus semiplectens K.Schum

Hoodia

juttac Dinter

officinalis (N.E.Br) Plowes subsp. delactiana (Dinter) Bruyns ruschii Dinter

tricbneri (Vel) Brums

Huernia

hallii E Lamb \& B MLamh

plowesii L. C. Leuch

Larryleachia tirasmontana Plowe's $=$ Lavrania picta (N.E. Br.) Plowes subsp. panipunc lara Bruyns

Lavrania haagnerac Plowes

Microloma

hereroense Hammorp

penicillatum Schlst

Orbea

albocastanea (Marloth) Bruvn:

maculata (N. E Br) L. C Leach

- subsp kaokuensis Brums

subsp. rangeana (Dinter \& A Berger) Bruyns

Raphionacme

haeneliae Venter \& R.L.Verh

namibiana benter \& $R L$ berh
Stapelia

kwebensis N.E.Br. = Stapelia longipedicellata (A.Berger) N.E.Br., not endemic

pearsonii N.E.Br

* remota $R . A . D$ ver

schinzil A.Benger \& Schltr.

*var. bergeriana (Dinter) L.C.Leach

var. schinzi

-Stapeliopsis urniflora Lavranos

Stigmatorhynchus hereroensis Schltr.

Tridentea

marientalensis (Nel) L.C.Leach subsp. albipilosa (Giess) L.C.Leach -pachyrrhiza (Dinter) L.C.Leach

Tromotriche ruschiana (Dinter) Brunns

-Tylophora fleckii (Schltr.) N.E.Br.

Aponogetonaceae

Aponogeton azureus H.Bruggen

\section{Asphodelaceae}

Aloe

argenticauda Merm. \& Giess

asperifolia A.Berger

corallina I. Verd.

dewinteri Giess

-dinteri A Benger

erinacea D.S. Hardy

*hereroensis Engl. var. lutea A.Berger

namibensis Giess

omavandae Van Jaarsi

pachygaster Dinter

sladeniana Pole Evans

viridiflora Reynolds

Bulbine

caput-medusae G. Will

francescae G. Will \& Baijnath

namaensis $\operatorname{Schinz}$

praemorsa $=$ Bulbine tetraphylla Dinter, not endemic

*rhopalophylla Dinter

Trachyandra

ensifolia (Sölch) Roessler

glandulosa (Dinter) Oberm.

lanata (Dinter) Oherm.

peculiaris (Diner) Oberm

\section{Asteraceae}

Amphiglossa thuja (Merxm.) Koekemoer

Anisopappus

pinnatifidus (Klatt) O. Hoffm. ex Hutch.

pseudopinnatifidus S.Ortiz \& Paiva

Antiphiona

fragrans (Merrm.) Meram

pinnatisecta (S.Moore) Merxm

Arctotis frutescens T.Norl.

Aspilia eenii S.Moore

Berkheya schinzii O.Hoffm.

Calostephane marlothiana $O$.Hoffm.

* Chrysocoma puberula Merxm

Crassocephalum coeruleum (O.Hoffm.) R.E.Fr

Dauresia alliariifolia (O. Hoffm.) B Nord \& Pelser $=$ Senecio alliariifolius O.Hoffm.

Dicoma

cuneneensis Wild

dinteri S.Moone

*obconica S.Ortiz \& Pulgar

Eremothamnus marlothianus $O$. Hoffm

Eriocephalus

dinteri S.Moore

giessii MA.N.Müller

kingesii Merrm \& Eberle

klinghardtensis MAN. Müller

pinnatus $O$.Hoffm

Euryops

mucosus $B$. Nond

walterorum Merxm

Felicia

alba Gran

gunillae B. Nord

smaragdina (S M(xore) Merrm

* (iaruleum schinzii OHoffm subsp crinitum (Dinter) Merrm

Gazania thermalis Dinter 


\section{Geigeria}

odontoptera O.Hoffm.

ornativa $O$. Hoffm. subsp. ornativa var. filifolia (Mattf.) S.Ortiz \& Rodr.Oubiña $=$ G. englerana Muschl. \& Geigeria otaviensis (Merxm.) Merxm.

pilifera Hutch.

plumosa Muschl.

*subsp. angustifolia S.Ortiz \& Rodr.Oubiña

subsp. brachycephala S. Ortiz \& Rodr.Oubiña $=$ G. brachycephala Muschl.

rigida $O . H o f f m$.

Gorteria diffusa Thunb. subsp. parviligulata Roessler

Helichrysum

amboense Schinz

deserticola Hilliard

erubescens Hilliard

marlothianum O.Hoffm.

Lasiopogon

ponticulus Hilliard

volkii (B.Nord.) Hilliard

Myxopappus hereroensis (O.Hoffm.) Källersjö

Nicolasia

heterophylla S.Moore

subsp. affinis (S.Moore) Merxm.

subsp. heterophylla

Nidorella nordenstamii Wild

Nolletia tenuifolia Mattf.

*Norlindhia aptera B.Nord.

Ondetia linearis Benth.

Osteospermum

montanum Klatt

muricatum E.Mey. ex DC. subsp. longiradiatum T.Norl

Othonna

brandbergensis B.Nord.

clavifolia Marloth

-graveolens O.Hoffm.

sparsiflora (S.Moore) B.Nord.

Pegolettia

pinnatilobata (Klatt) O.Hoffm. ex Dinter

plumosa M.D.Hend

Pentatrichia

avasmontana Merxm.

rehmii (Merxm.) Merxm

* Philyrophyllum brandbergense P P J.Herman

Pentzia tomentosa B.Nord.

Pteronia

eenii S.Moore

polygalifolia $O . H o f f m$.

pomonae Merxm

rangei Muschl.

spinulosa E.Phillips

Rennera eenii (S.Moore) Källersjö

Senecio

engleranus $O$. Hoffm.

giessii Merxm.

hermannii B.Nord.

windhoekensis Merxm

Sphaeranthus wattii Giess ex Merrm.

Tripteris nervosa Hurch.

Ursinia frutescens Dinter

Vernonia

obionifolia $\mathrm{O}$. Hoffm

subsp. dentata Merxm.

subsp. obionifolia

Boraginaceae

*Ehretia namibiensis Retief \& A.E.van Wik subsp. kaokoensis Retief \& A.E. van Wh

Heliotropium albiflonum Engl.

-Trichodesma angustifolium Han: subsp. argenteum Retief \& A.E.van Wvk

\section{Brassicaceae}

Heliophila

* deserticola Schltr var. micrantha A.Schreib.

obibensis Marais

\section{Burseraceae}

Commiphora

* dinteri Engl.

giessii J.J.A.van der Walt

*kaokoensis W Swanepoel kraeuseliana Heine

-saxicola Engl.

-virgata Engl.

\section{Campanulaceae}

Namacodon schinzianum (Markgr.) Thulin

Wahlenbergia

densicaulis Brehmer

erophiloides Markgr

*intricata (Dinter \& Markgraf) P.Craven, ined. = Lightfootia dinteri Engl. ex Dinter

subumbellata Markgr.

\section{Capparaceae}

Cleome

carnosa (Pax) Gilg \& Gilg-Ben.

foliosa Hook.f. var. namibensis (Kers) Codd

labumifolia Roessler

suffruticosa Schinz

\section{Chenopodiaceae}

*Chenopodium amboanum (Murr) Aellen

Salsola

albisepala Aellen

arborea C.A.Sm. ex Aellen

*aroabica Botsch.

campyloptera Botsch

cauliflora Botsch.

columnaris Botsch

cryptoptera Aellen

denudata Botsch

dinteri Botsch.

dolichostigma Botsch

etoshensis Botsch.

* garubica Botsch.

gemmata Botsch

giessii Botsch.

hoanibica Botsch.

hottentottica Botsch.

huabica Botsch

kleinfonteini Botsch

koichabica Botsch

marginata Botsch.

mirabilis Botsch

namibica Botsch

okaukuejensis Botsch.

* omaruruensis Botsch.

*parviflora Botsch

procera Botsch.

ptiloptera Botsch

robinsonii Botsch.

*schreiberae Botsch

scopiformis Botsch

seminuda Botsch.

*seydelii Botsch.

spenceri Botsch

swakopmundi Botsch

ugabica Botsch.

unjabica Botsch

Suaeda

articulata Aellen

salina B.Nord

\section{Colchicaceae}

Androcymbium exiguum Roessler subsp. exiguum

Ornithoglossum calcicola $K$.Krause \& Dinter.

\section{Convolvulaceae}

Convolvulus argillicola Pilg

Merremia

bipinnatipartita (Engl.) Hallier f.

guerichii A Meeuse

\section{Crassulaceae}

Adromischus

schuldtianus (Poelln.) Poelln.

* subsp. brandbergensis B. Nord \& Van Jaarsi

subsp. juttae (Poelln) Toelken

subsp. schuldtianus 
Crassula

aurusbergensis G.Will.

ausensis Hutchison

subsp. ausensis

subsp. giessii (Friedrich) Toelken

* subsp. titanopsis Pavelka

elegans $S$ chönland \& Baker f. subsp. namibensis (Friedrich) Toelken

luederitzii Schönland

numaisensis Friedrich

Tylecodon

aridimontanus G.Will.

*aurusbergensis G.Will. \& Van Jaarsv.

\section{Cucurbitaceae}

Citrullus rehmii De Winter

Cucumella clavipetiolata J.H.Kirkbr.

\section{Cyperaceae}

- Bulbostylis mucronata C.B.Clarke

Cyperus rehmii Merxm

\section{Ebenaceae}

Euclea asperrima Friedr.-Holzh.

\section{Eriospermaceae}

Eriospermum

buchubergense Dinter, insuff. known

citrinum P.L.Perr

flexum P.L.Perry

*graniticolum Dinter ex Poelln., insuff. known

halenbergense Dinter

lavranosii P.L.Perry

volkmanniae Dinter

\section{Euphorbiaceae}

Euphorbia

angrae $N . E . B r$.

baliola $N . E . B r$

caperonioides R.A.Dyer \& P.G.Mey.

chamaesycoides $B$. Nord.

- cibdela N.E.Br

damarana L.C.Leach

friedrichiae Dinter

giessii L.C.Leach

insarmentosa P.G.MeV:

juttae Dinter

kaokoensis (A.C.Whire, R.A.Dyer \& B.Sloane) L.C.Leach

lavrani L.C.Leach

leistneri R.H.Archer

mauritanica $L$. var. foetens Dinter ex A.C.White, R.A.Dyer \& B. Sloane

monteiroi Hook.f. subsp. brandbergensis B. Nord

namibensis Marloth

namuskluftensis L.C.Leach

otjipembana L.C.Leach

pergracilis $P$ G.Mey:

* pseudoduseimata A.C. White, R.A.Dver \& B.Sloane

rudis $N . E . B r$

* spartaria N.E.Br.

* spinea N.E.Br.

venenata Marloth

verruculosa N.E.Br

volkmanniac Dinter

Phyllanthus dinteri Pax

Tragia

dinteri Par

lancifolia Dinter ex Pax \& KHoffm

\section{Fabaceace}

-Acacia montis-usti Merrm \& A. Schreib.

Bolusia amborensis (Schinz) Horms

Caesalpinia

merxmuellerana $A$ Schreit

pearsonii I Bolus

Crotalaria

aurea Dinter ex Buker f

colorata $S_{\text {Chinz subsp. colorata }}$

kurtii Schinz

Decorsca dinteri (Harms) Verde.

Elephantorrhiza

rangei Harms:

schinziana Dinter
Eriosema harmsiana Dinter

Erythrina decora Harms

Haematoxylum dinteri (Harms) Harms

Indigofera

acanthoclada Dinter

anabibensis $A$.Schreib

giessii A.Schreib.

hochstetteri Baker subsp. streyana (Merxm.) A.Schreib.

merxmuelleri A.Schreib.

pechuelii Kuntze

rautanenii Baker $f$.

Lebeckia

dinteri Harms

obovata Schinz

Lessertia

acanthorhachis (Dinter) Dinter

cryptantha Dinter

eremicola Dinter

Lotononis

bracteosa B.-Evan Whk

mirabilis Dinter

pachycarpa Dinter ex B.-E.van Whk

pallidirosea Dinter \& Harms

schreiberi B.-E.van Wik

Sesbania pachycarpa $D C$. subsp. dinterana J.B.Gillett

Tephrosia

griseola H.ML.F.orbes

monophylla Schinz

pallida H.M.L.Forbes

Frankeniaceae

Frankenia pomonensis Pohnert

\section{Geraniaceae}

Monsonia

deserticola Dinter ex R.Knuth

drudeana Schinz

ignorata Merxm. \& A.Schreib.

trilobata Kers

Pelargonium

cortusifolium L'Hér

mirabile Dinter

otaviense R.Knuth

paniculatum Jacq

Sarcocaulon

inerme Rehm

marlothii Engl.

peniculinum Moffet

\section{Hyacinthaceae}

Albuca

amboensis (Schinz) Oberm.

*englerana K Krause \& Dinter

hereroensis Schinz

* karasbergensis $P E$, Glover

"reflexa Dinter \& K.Krause

Drimia

namibensis (Oberm.) J.C.Manning \& Goldblatt = Rhadamanthus namibensis Oberm.

secunda (B.Nord.) J.C.Manning \& Goldblatt $=$ Rhadamanthus secundus B.Nord.

Lachenalia

giessii W.F Barker

klinghardtiana Dinter

namibiensis WFBarker

nutans G.D.Duncan

pearsonii (P.E.Glover) W F Barker

Ledebouria scabrida Jessop

Omithogalum

candidum Oberm

rautanenii Schinz

stapffii Schinz

tubiforme (Oberm, Oberm.

\section{Hyposidaceae}

Hypoxis dinteri Nel

\section{Iridaceat}

Babiana longicollis Dinter

- Ferraria schacferi Dinter

I.apeirousia

avasmontana Dinter

gracilis Vuupe' 
Moraea

garipensis Goldblatt

* graniticola Goldblatt

hexaglottis Goldblatt

namibensis Goldblatt

rigidifolia Goldblatt

\section{Kirkiaceae}

Kirkia dewinteri Merxm. \& Heine

\section{Lamiaceae}

Acrotome fleckii (Gürke) Launert

Acollanthus namibiensis Ryding

Hemizygia floccosa Launert

Plectranthus

dinteri Briq

unguentarius Codd

Stachys dinteri Launer

- Tetradenia kaokoensis Van Jaarsv. \& A.E.van Wyk

\section{Lobeliaceae}

Lobelia hereroensis Schinz

\section{Loranthaceae}

Agelanthus discolor (Schinz) Balle

\section{Lythraceae}

Nesaea luederitzii Koehne var. hereroensis Koehne

\section{Malvaceae}

Hibiscus

dinteri Hochr

discophorus Hochr

fleckii Gürke

merxmuelleri Roessler

sulfuranthus $\mathrm{Clbr}$.

Pavonia rehmannii Szyszyl.

\section{Mesembryanthemaceae}

Amphibolia saginata (L.Bolus) H.E.K.Hartmann

Antimima

argentea (L.Bolus) H.E.K.Hartmann

aurasensis H.E.K.Hartmann

buchubergensis (Dinter) H.E.K.Hartmann

dolomitica (Dinter) H.E.K.Hartmann

eendomensis (Dinter) H.E.K.Hartmann

modesta (L.Bolus) H.E.K.Hartmann

quarzitica (Dinter) H.E.K.Harmann

Astridia hallii L. Bolus

Brownanthus

- arenosus (Schinz) Ihlenf. \& Bittrich

namibensis (Marloth) Bullock

pubescens (N.E.Br. ex Maasss) Bullock

Cephalophyllum

* compressum L. Bolus

confusum (Dinter) Dinter \& Schwantes

Cheiridopsis caroli-schmidtii (Dinter \& A.Berger) N.E.Br

Conophytum

halenbergense (Dinter \& Schwantes) N.E.Br.

klinghardtense Rawe

subsp, baradii (Rawe) S.A.Hammer

subsp. klinghardtense

quaesitum (N.E.Br.) N.E.Br. subsp. densipunctum (L.Bolus) S.A.Hammer

ricardianum Loesch \& Tischer

subsp. ricardianum

subsp. rubiflorum Tischer

taylorianum (Dinter \& Schwantes) N.E.Br

subsp. emianum (Loesch \& Tischer) de Boer ex S.A. Hammer subsp. taylorianum

Delosperma klinghardtianum Schwantes

Dinteranthus microspermus (Dinter \& Derenb.) Schwantes subsp. impunctatus N.Sauer

*Dracophilus delaetinus (Dinter) Dinter \& Schwantes

Drosanthemum

nordenstamii L. Bolus

pauper (Dinter) Dinter \& Schwantes

Eberlanzia clausa (Dinter) Schwantes

Ebracteola

derenbergiana (Dinter) Dinter \& Schwantes

montis-molikei (Dinter) Dinter \& Schwantes
Fenestraria rhopalophylla (Schltr. \& Diels) N.E.Br. subsp. rhopalophylla

Jensenobotrya lossowiana A.G.J.Herre

Juttadinteria

attenuata Walgate

* ausensis (L.Bolus) Schwantes

deserticola (Marloth) Schwantes

simpsonii (Dinter) Schwantes

Lithops

dinteri Schwantes

subsp. dinteri

* subsp. multipunctata (de Boer) D.T.Cole

* francisci (Dinter \& Schuantes) N.E.Br

* gracilidelineata Dinter subsp. brandbergensis (de Boer) D.T.Cole

* hermetica D.T.Cole

julii (Dinter \& Schwantes) N.E.Br. subsp. julii

karasmontana (Dinter \& Schwantes) N.E.Br.

*subsp. bella (N.E.Br.) D.T.Cole

* subsp. eberlanzii (Dinter \& Schwantes) D.T.Cole

*optica (Marloth) N.E.Br.

pseudotruncatella (A.Berger) N.E.B

* subsp. archerae (de Boer) D.T.Cole

* subsp. dendritica (Nel) D.T.Cole

* subsp. volkii (Schwantes ex de Boer \& Boom) D.T.Cole

*ruschiorum (Dinter \& Schwantes) N.E.Br.

schwantesii Dinter

*subsp. gebseri (de Boer) D.T.Cole

subsp. schwantesii

*vallis-mariae (Dinter \& Schwantes) N.E.Br.

wemeri Schwantes ex H.Jacobsen

* Malephora engleriana (Dinter \& A.Berger) Schwantes

Mesembryanthemum pellitum Friedrich

Namibia

cinerea (Marloth) Dinter \& Schwantes $=$ Namibia ponderosa

(Dinter \& Schwantes) Dinter \& Schwantes

pomonae (Dinter) Dinter \& Schwantes ex Walgate

Psammophora

*nissenii (Dinter) Dinter \& Schwantes

* saxicola H.E.K.Harimann

Psilocaulon

gessertianum (Dinter \& A Berger) Dinter \& Schwantes

-salicomioides (Pax) Schwantes

Ruschia

deminuta L.Bolus

*namusmontana Friedrich

*odontocalyx (Schltr. \& Diels) Schwantes

* pollardii Friedrich

* ruschiana (Dinter) Dinter \& Schwantes

vulvaria (Dinter) Schwantes

Ruschianthus falcatus $L$. Bolus

Schwantesia

constanceae N.Zimm

succumbens (Dinter) Dinter

Synaptophyllum juttae (Dinter \& A.Berger) N.E.Br

* Titanopsis schwantesii (Schwantes) Schwantes

*Trichodiadema littlewoodii L. Bolus

\section{Molluginaceae}

Corbichonia rubriviolacea (Friedrich) Jeffre

Hypertelis caespitosa Friedrich

Mollugo walteri Friedrich

Suessenguthiella caespitosa Friedrich

\section{Nyctaginaceae}

Boerhavia deserticola Codd

Commicarpus

*decipiens Meikle

fruticosus Pohner

\section{Orobanchaceae}

Alectra

pseudobarleriae (Dinter) Dinter

schoenfelderi Dinter \& Melch

\section{Oxalidaceae}

Oxalis

ausensis $R$ Kinuth

hunsbergensis ined. 


\author{
Oxalis (cont.) \\ luederitzii Schinz \\ pseudo-cemua R.Knuth \\ schaeferi R.Knuth
}

\section{Passifloraceae}

-Adenia pechuelii (Engl.) Harms

\section{Pedaliaceae}

Rogeria bigibbosa Engl.

Sesamothamnus leistneranus, ined. = De Winter \& Leistner 5504

Sesamum

abbreviatum Merxm.

marlothii Engl.

\section{Plumbaginaceae}

Limonium dyeri Lincz.

Plumbago

pearsonii L. Bolus

wissii Friedrich

\section{Poaceae}

*Brachiaria schoenfelderi C.E.Hubb. \& Schweick.

Eragrostis

aristata De Winter

kingesii De Winter

omahekensis De Winter

pygmaea $D e$ Winter

sabinae Launert

scopelophila Pilg.

stenothyrsa Pilg.

walteri Pilg

-Kaokochloa nigrirostris De Winter

Merxmuellera rangei (Pilg.) Conert

* Panicum pearsonii F.Bolus

Pennisetum foermeranum Leeke

Pogonarthria leiarthra Hack.

Setaria finita Launert

Sporobolus nebulosus Hack. (endemic to southem Africa)

Stipagrostis

-damarensis (Mez) De Winter

garubensis (Pilg.) De Winter

gonatostachys (Pilg.) De Winter

-hermannii (Mez) De Winter

lanipes $(M e z)$ De Winter

namibensis De Winter

pellytronis De Winter

-ramulosa De Winter

sabulicola (Pilg.) De Winter

seelyae De Winter

\section{Polygalaceae}

- Polygala guerichiana Engl.

\section{Portulacaceae}

Anacampseros filamentosa (Haw.) Sims subsp. tomentosa (A Benger) Gerhaulet

Avonia dinteri (Schinz) G.D.Rowley = Anacampseros dinteri Schinz - Ceraria longipedunculata Merxm. \& Podlech

\section{Rubiaceae}

Amphiasma

divaricatum (Engl.) Bremek

merenskyanum Bremek.

Kohautia

amboensis (Schinz) Bremek.

azurea (Dinter \& K Krause) Bremek

\section{Santalaceae}

Thesium xerophyticum A. W. Hill

\section{Scrophulariaceae}

Anticharis

ebracteata Schinz

imbricata Schinz

inflata Marloth \& Engl.

Aptosimum

arenarium Engl

suberosum FE. Weber

Chamaegigas intrepidus Dinter ex Heil

Cromidon pusillum (Roessler) Hilliard

Diclis tenuissima Pilg.

Dintera pterocaulis Stapf
Jamesbrittenia

acutiloba (Pilg.) Hilliard

barbata Hilliard

bicolor (Dinter) Hilliard

chenopodioides Hilliard

dolomitica Hilliard

fimbriata Hilliard

fleckii (Thell.) Hilliard

fragilis (Pilg.) Hilliard

giessii Hilliard

hereroensis (Engl.) Hilliard

lyperioides (Engl.) Hilliard

pallida (Pilg.) Hilliard

pilgeriana (Dinter) Hilliard

primulifora (Thell.) Hilliard

sessilifolia (Diels) Hilliard

Manulea

dubia (Skan) Overkott ex Roessler

namibensis (Roessler) Hilliard

tenella Hilliard

Manuleopsis dinteri Thell.

Nemesia

karasbergensis L.Bolus

violiflora Roessler

-Phyllopodium hispidulum (Thell.) Hilliard

Selago

amboensis Rolfe

lepida Hilliard

nachtigalii Rolfe

\section{Solanaceae}

Lycium grandicalyx Jouber \& A.M. Venter

Nicotiana africana Merxm

Solanum

damarense Bitter

dinteri Bitter

rigescentoides $\mathrm{Hurch}$.

\section{Sterculiaceae}

Dombeya rotundifolia (Hochst.) Planch var. velutina I.Verd.

Hermannia

amabilis Marloth ex K.Schum.

* complicata Engl.

elliottiana (Harv.) K.Schum.

engleri Schinz

glandulosissima Engl.

juttae Dinter \& Engl.

merxmuelleri Friedr-Holzh

minimifolia Friedr-Holzh

solaniflora K Schum.

Tecophilaeaceae

- Eremiolirion amboensis = Cvanella amboensis Schin=

\section{Tiliaceae}

Corchorus merxmuelleri Wild

\section{Turneraceae}

Tumera oculata Sron var. paucipilosa Oherm.

\section{Verbenaceae}

Priva auricoccea A.Meeuse

\section{Vitaceae}

Cyphostemma

bainesii (Hook.f Desc.

-juttae (Dinter \& Gilg) Desc.

omburense (Gilg \& M.Brandi) Desc.

\section{Zygophyllaceae}

Neoluederitzia sericeocarpa Schinz

Zygophyllum

applanatum Van $\mathrm{ZV}$

cylindrifolium Schinz

giessii Merxm \& A. Schreih

hirticaule Vian $\mathrm{Zv} /$

longistipulatum Schinz

-stapffii Schinz, previously known as Z orbicularum in Angola 